\title{
Сравнительный анализ изменений природно-антропогенных комплексов береговой зоны Тихоокеанской России
}

\author{
ЕРМОШИН В.В., БАЗАРОВ К.Ю. \\ Федеральное государственное бюджетное учреждение науки \\ Тихоокеанский институт географии ДВО РАН, Владивосток \\ yermoshin@tigdvo.ru
}

\begin{abstract}
Аннотация. Рассмотрен опыт применения разновременных спутниковых фото- и спектрозональных снимков для картографирования изменений природно-антропогенных комплексов ключевых районов береговых (прибрежных) зон за последние 30-40 лет. Показана необходимость анализа природных состояний и антропогенных изменений береговой зоны Тихоокеанской России как условий жизнедеятельности и показателя рациональности природопользования. Показано, что наиболее актуальным является проведение таких оценок в существующих и потенциальных «точках роста» - узловых приморских районах развития. Перечислены пригодные для решения поставленной задачи и доступные в сети Интернет данные дистанционного зондирования, их особенности и характеристики, обусловлены критерии отбора. Рассмотрена методика дешифрирования данных дистанционного зондирования и сложности при использовании разновременных и разнотипных космических данных. Получены геоинформационные слои, отображающие структуру природно-антропогенных комплексов. Проведен сравнительный анализ изменений природных и антропогенных комплексов потенциального узлового района развития «Ольга - бухта Владимира» и южного участка биосферного Сихотэ-Алинского заповедника, условно принятого за эталонный, не затронутый антропогенным воздействием. Установлено, что изменения природных ландшафтов прибрежной зоны Сихотэ-Алинского заповедника происходят в естественном ключе без антропогенного вмешательства, качественных изменений структуры ландшафтов не наблюдается, расчеты изменений значений вегетационного индекса за соответствующие периоды времени демонстрируют положительную динамику, что подтверждает увеличение фитомассы при естественных сукцессиях. Результаты дешифрирования, геоинформационное картографирование и проведенный сравнительный анализ показывают, что критических и даже существенных изменений в ландшафтной структуре рассматриваемого узлового района и территорий, находящихся в зоне его влияния, не произошло. Утверждается, что доминирующее положение лесных и редколесных ландшафтов создаст эффект буфера при дальнейшем потенциальном развитии этих территорий как узловых районов развития в береговых зонах и обеспечит устойчивость этих территорий в отношении сохранения качества окружающей среды при возможном увеличении антропогенной нагрузки.
\end{abstract}

Ключевые слова: береговая зона, природно-антропогенные комплексы, дешифрирование, картографирование.

\section{Comparative analysis of changes in natural-antropogenic complexes of the Pacific Russia coastal zone}

\author{
ERMOSHIN V.V., BAZAROV K.Yu. \\ Pacific Geographical Institute FEB RAS, Vladivostok \\ yermoshin@tigdvo.ru
}

\begin{abstract}
In the article the experience of application of spectrum-zonal remote sensing images occurring at different times for mapping the changes of nature-anthropogenic complexes of the key areas of coastal zones is considered for last
\end{abstract}


30-40 years. Necessity of the analysis of natural conditions and anthropogenic changes of the coastal zone of Pacific Russia as the conditions of ability to live and the indicator of rationality of nature use at a new level is considered. It is shown that carrying out such estimations in the existing and potential "growth points"- core seaside areas of development is the most actual. The obtainable Internet data on remote sensing, their features, and characteristics suitable for decision of a set task are listed; the criteria of selection are conditioned. The technique of interpretation of remote sensing data and complexity, while using the space data of the different type and occurring at different time, is considered. As a result of implementation of the work, the GIS-layers displaying the structure of nature-anthropogenic complexes have been obtained. The comparative analysis of the changes of natural and anthropogenic complexes of potential core area of development "Olga-Vladimir Bay" and the southern site of the biosphere Sikhote-Alin reserve, conditionally accepted as a natural standard not touched by the anthropogenic influence, has been carried out. It is established that the changes of natural landscapes of the coastal zone of the Sikhote-Alin reserve occur naturally without anthropogenic intervention; the qualitative changes of the structure of landscapes has not been observed; the calculations of the changes of the values of a vegetative index for the corresponding periods of time show positive dynamics that confirms an increase in phytomass in case of natural successions. The results of interpretation of geoinformation mapping and the carried out comparative analysis show that any critical and essential changes occurred in the landscape structure of the considered key area and on the territories located in the zone of its influence. It is approved that the dominating position of the forest and open woodland landscapes will create buffer effect and will provide stability of these territories relatively to preservation of quality of the environment in case of the possible increase in anthropogenic load if further potential development of these territories happens as the key areas of development in coastal zones.

Keywords: coastal zone, natural-anthropogenic complexes, remote sensing analysis, GIS-mapping.

\section{Введение, постановка проблемы}

Береговая зона (БЗ) Дальнего Востока России как составная часть Тихоокеанской России (ТР), включающая прибрежную сушу и акваторию, а также прилегающие к ней приморские регионы, привлекает в последнее время большое внимание. Именно здесь пересекаются взаимные интересы государственного регулирования, бизнеса и устойчивого природопользования [1-4]. При этом фактическая социально-экономическая освоенность данного пространства незначительна и со второй половины 20 века на его большей части она сокращается, а территориальная организация населения и освоенность в БЗ представлена сочетанием редких очагов хозяйственной активности и практически неосвоенных территорий [5]. Необходимость оценки природно-экологических причин потери освоенности, а также большая вероятность нарастания в будущем нового хозяйственного освоения приморских территорий ТР требует анализа комплекса природных условий береговой зоны, состояния и качества окружающей среды - как условий жизнедеятельности и показателя рациональности природопользования [6].

Наиболее актуальным является проведение таких оценок в существующих и потенциальных «точках роста» - узловых приморских районах развития (УПРР) [5-7]. Узловые приморские районы развития - это части БЗ с реальным уровнем освоенности и перспективами ее развития, а также потенциально перспективные для освоения как точки локального роста или опорные территории. Нами подчеркивалось, что ввиду недостаточности сведений по природному, ресурсному и экологическому состоянию этих территорий и несопоставимости имеющихся разнородных данных наиболее корректно такие исследования начинать с картографирования изменений природно-антропогенных комплексов узловых районов прибрежной зоны на основе анализа временных рядов ДДЗ. Приоритетное использование частей БЗ ТР с лучшими в пределах региона природно-хозяйственными условиями для освоения требует их определения, выделения и более детального изучения. Оптимально это реализовывать на различных масштабных уровнях.

Мелкомасштабное районирование по природным условиям хозяйственного освоения БЗ ТР проводилось ранее неоднократно [7, 8-10]. Не углубляясь в дискуссию о принципах и методах проведенных районирований и зонирований, мы в своем исследовании опираемся на схему районирования БЗ ТР по природным условиям хозяйственного освоения, обоснованную в работе [5]. При этом в качестве основных факторов дифференциации природных условий рассматривается изменение теплообеспеченности и зональных типов растительности. Предложено пространство БЗ ТР разделить на три пояса: Арктический, 
Субарктический и Умеренный. Дополнительно выделено два сектора: островной и материковый. Районирование пространства БЗ ТР по условиям природопользования и жизнедеятельности включает в качестве основных единиц природно-хозяйственные пояса; в пределах поясов - подзоны (выделяются с использованием биогеографических и экорегиональных границ); в пределах подзон - природно-хозяйственные округа.

Выделение и детальное исследование, включая картографирование на основе дешифрирования ДДЗ изменений природно-антропогенных комплексов УПРР, было проведено нами ранее [6]. Было показано, что лучшими в регионе природными условиями хозяйственного освоения обладает географическое пространство в пределах умеренного южно-таежного пояса с умеренно благоприятными и относительно комфортными характеристиками для жизнедеятельности и устойчивого природопользования. Наши исследования были проведены в шести основных УПРР именно в подзонах этого пояса: залив Петра Великого (в т.ч. Хасанский район: Славянка; Зарубино; Находка); залив Ольги - залив Владимира; Ванино - Советская Гавань; Петропавловск-Камчатский - Елизово.

Результаты дешифрирования ДДЗ, геоинформационное картографирование и проведенный анализ показали, что критических и даже существенных изменений в ландшафтной структуре рассматриваемых УРР и территорий, находящихся в зоне их влияния, не произошло. На данном этапе целесообразно провести сравнительный анализ изменений природно-антропогенных комплексов в пределах УППР и природных ландшафтных комплексов на прибрежных территориях, не затронутых антропогенной деятельностью. Подобная постановка вопроса может дать ответ на важный вопрос - насколько велики различия в изменениях, каков «запас прочности» предполагаемых районов развития до их вовлечения в более интенсивную хозяйственную деятельность. Для сравнительного анализа были выбраны два района береговой зоны: фрагмент Сихотэ-Алинского биосферного заповедника в качестве природного эталона и УПРР «Ольга-залив Владимир», результаты картографирования природно-антропогенных комплексов которого ранее не освещались (рис. 1). Оба они расположены в умеренном южно-таежном поясе в пределах подзоны северных и средних хвойно-широколиственных лесов.

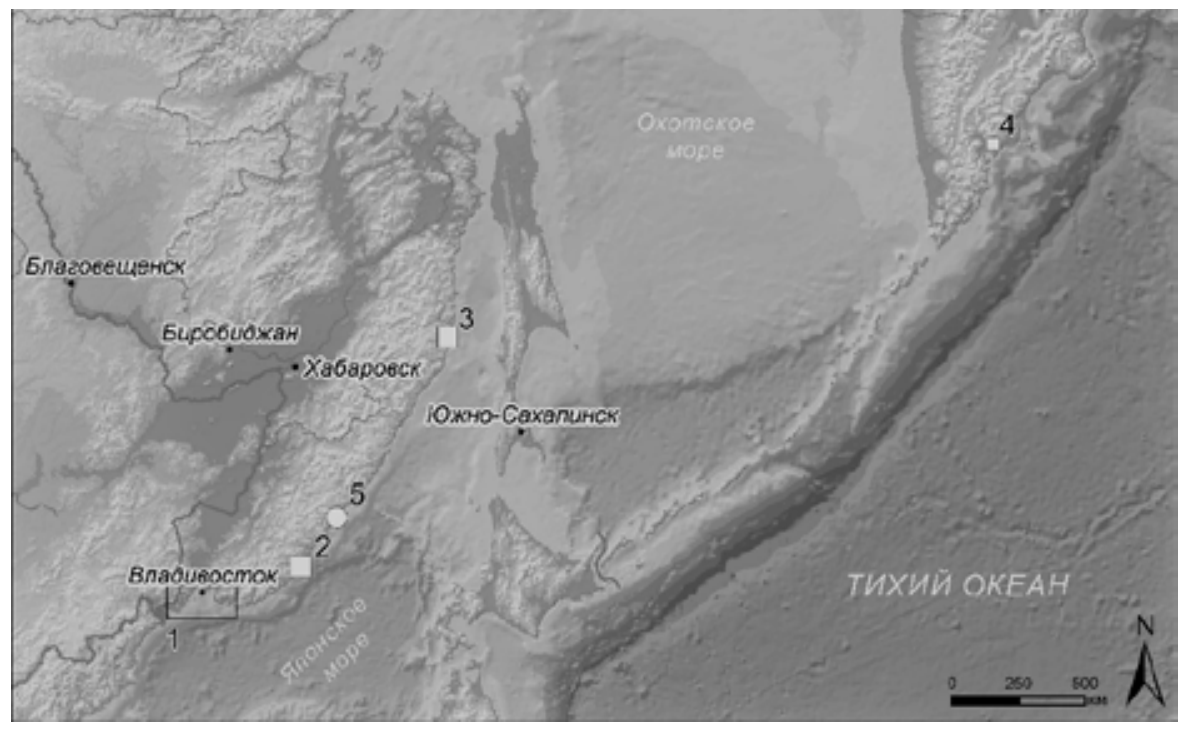

Рис. 1. Расположение исследуемых районов. Условные обозначения: 1 - Залив Петра Великого (включая п. Славянка; п. Зарубино); 2 - Ольга-залив Владимир; 3 - г. Советская Гавань - пос. Ванино; 4 - г. Петропавловск-Камчатский (включая пос. Елизово); 5 - прибрежный участок СихотэАлинского заповедника

Fig. 1. The location of the areas under study. Legend: 1 - Great Peter Bay (with Slanynka and Zarubino settlements); 2 - Olga-Vladimir Bay; 3 - Sovetskaya Gavan-Vanino; 4 - Petropavlovsk-Kamchatskii (with Elizovo); 5 - coastal part of Sikhote-Alin reserve 


\section{Материалы и методы}

Для оценки динамики антропогенных и природных ландшафтов, изменений окружающей среды были отобраны и использованы при дешифрировании разнотипные и разновременные данные дистанционного зондирования, доступные посредством сети Интернет в виде архивов данных или в режиме «онлайн», а также космические снимки (КС), имеющиеся в базе данных ТИГ ДВО РАН. Основные результаты были получены при использовании спектрозональных ДДЗ, позволяющих достаточно уверенно разделять и опознавать разнотипные объекты за счет различий в их спектральных характеристиках. В работе были использованы данные с космических аппаратов (КА) Landsat-5, Landsat-7, Landsat-8 и Sentinel-2 [11-14] (табл. 1).

\section{Таблица 1}

Космические снимки, использованные при дешифрировании и оценке изменений природных и антропогенных комплексов

Table 1. Remote sensing images used to decrypt and estimate changes in natural and anthropogenic complexes

\begin{tabular}{|c|c|c|c|}
\hline KA & Сенсор & Дата съемки & Район исследования \\
\hline Sentinel-2 & MSI & 2016.09 .19 & \multirow{5}{*}{$\begin{array}{l}\text { Узловой район развития } \\
\text { Ольга - залив Владимира }\end{array}$} \\
\hline Sentinel-2 & MSI & 2017.01 .07 & \\
\hline Landsat- 8 & OLI & 2016.08 .27 & \\
\hline Landsat-5 & TM & 1992.09 .10 & \\
\hline Landsat-5 & TM & 1991.12.13 & \\
\hline Landsat-5 & TM & 1992.09 .03 & \multirow{3}{*}{$\begin{array}{l}\text { Сихотэ-Алинский } \\
\text { заповедник (участок) }\end{array}$} \\
\hline Landsat-7 & ETM+ & 2002.09 .07 & \\
\hline Landsat- 8 & OLI & 2013.09 .29 & \\
\hline
\end{tabular}

Для конкретного временного состояния на каждый исследуемый узловой район при дешифрировании использовалось по два снимка - за август/сентябрь и декабрь. Временной диапазон охватывал как минимум 20-25 лет. Первый временной рубеж был определен концом 80 - началом 90-х годов прошлого века. Второй временной рубеж - 2016 г. Выбор изображений, полученных во второй половине августа - первой половине сентября, обусловлен вегетационной фазой, позволяющей четко дифференцировать различные типы лиственной растительности и антропогенные объекты. Зимние снимки использовались для выделения ландшафтов с хвойными насаждениями. На всех КС отсутствие облачности составляло 90-100\%.

Для выделения водных объектов на основе спектрозональных данных был рассчитан модифицированный нормализованный разностный водный индекс - Modified Normalized Difference Water Index, MNDWI [15]. MNDWI позволяет уверено выделять водные поверхности за счет особенностей отражения в «зеленой» и инфракрасной зонах электромагнитного спектра.

Методика полуавтоматического дешифрирования детально изложена нами ранее [6, 16-17]. В соответствии с ней технология в обязательном порядке включает: радиометрическую калибровку, топографическую нормализацию, закладку эталонов - создание обучающих выборок, классификацию изображений, векторизацию, оформление. Дополнительно данные ДДЗ обрабатывались с использованием методов визуального дешифрирования в программной среде ArcGis 10.5. Результаты были оформлены в виде электронных тематических слоев в формате геобазы данных (.gdb). Непосредственно дешифрирование данных ДДЗ по временным срезам проводилось следующим образом: современный временной срез (2016-2017 гг.) создавался на базе данных ДЗ с КА Sentinel-2 и Landsat-8, интерпретация полученных результатов проводилась с привлечением полевых описаний и литературных данных, а также с использованием высокодетальных картографических подложек интернет-сервисов GoogleMap, BingMap, Ян- 
дексКарты и т.д. Затем полученный слой копировался и производилось редактирование согласно данным Д3 на начало 1990-х гг. (КА Landsat-5), используемым в качестве подложки. Ранее нами уже отмечалось, что при создании ретроспективного среза основной сложностью являлась разница в пространственном и радиометрическом разрешении используемых данных. Пространственное и радиометрическое разрешение сенсора MSI (КА Sentinel-2) составляет 10 м/пиксель и 16 бит соответственно; у сенсора OLI (KA Landsat-8) - 30 м/пиксель и 16 бит; у сенсора TM (КА Landsat-5) - 30 м/пиксель и 8 бит, что приводит к различиям в отображении одних и тех же объектов на разновременных снимках. Для решения данной проблемы была применена тонкая подстройка гистограммы ретроспективных данных.

В соответствии с методикой по фондовым материалам и результатам полевых исследований за разные годы для каждого района была сформирована классификация и легенда на каждый временной срез. Результаты классификации были конвертированы в векторный формат и отредактированы - изменены типы некоторых полигонов, для которых результаты классификации вызывали сомнения. Выделенным типам были присвоены условные знаки и скомпонованы карты ландшафтных комплексов прибрежной зоны для каждого временного среза. Для каждого временного среза были рассчитаны площадные характеристики, которые были визуализированы в виде гистограмм и таблиц. Полученные векторные тематические слои были «вычтены» друг из друга (оверлей-анализ), что позволило выделить участки, на которых произошла смена типа ландшафта. Полученные данные были генерализованы по площадному признаку. Далее рассчитывались изменения структуры ландшафтов в процентном соотношении относительно данных для 1992 г. Для УПРР в качестве расчетной площади принимался буфер радиусом 10 км, в пределах которого проводилось картографирование на различные временные срезы.

\section{Результаты и их обсуждение}

Прибрежный район развития «Ольга - залив Владимира». На Япономорском побережье между заливами П. Великого и Советской Гавани, которые обеспечены железнодорожными выходами к морю, район залива Владимира обладает максимальными географическими предпосылками для формирования точки локального роста. Здесь в наличии закрытая глубоководная бухта, реальные возможности и перспективы строительства железной дороги (Ново-Чугевка - Ольга), депрессивные населенные пункты, сохранившие элементы инфраструктуры (бывшие объекты Министерства обороны).

Возможности хозяйственного освоения данного узлового района прорабатывались и частично реализовывались в 1930-1950-е гг. в рамках программы «Индустриализация страны» и обеспечены проектной и предпроектной документацией. Например, строительство железной дороги в настоящее время перспективно рассматривать в варианте китайского транзита, а именно: Мудандзян - Цзиси - Ольга (Владимир). Данная дорога представляет интерес для иностранных инвесторов при условии предоставления возможности создания в районе пос. Ольга современного порта на основе расширения существующего порта Ольга или создания нового в бухте Владимира. Выбор данной части БЗ в качестве узлового района - это, в определенной мере, возвращение к идеям 60-х годов XIX в., когда он рассматривался как перспективное местоположение опорной базы Российской империи на юге Приморья [18]. В современных плановых документах данная линия отсутствует. Потенциальный интерес инвесторов КНР к выходу на Япономорское побережье, в первую очередь промышленных центров востока провинции Хэйлундзян, определяется поиском новых выходов к портам.

Узловой район «Ольга - залив Владимира» состоит из двух подрайонов: залив Ольги и залив Владимира. В данной статье в качестве примера детально рассмотрен подрайон Ольга (рис. 1, 2; табл. 2), по второму подрайону ситуация во многом идентичная. 

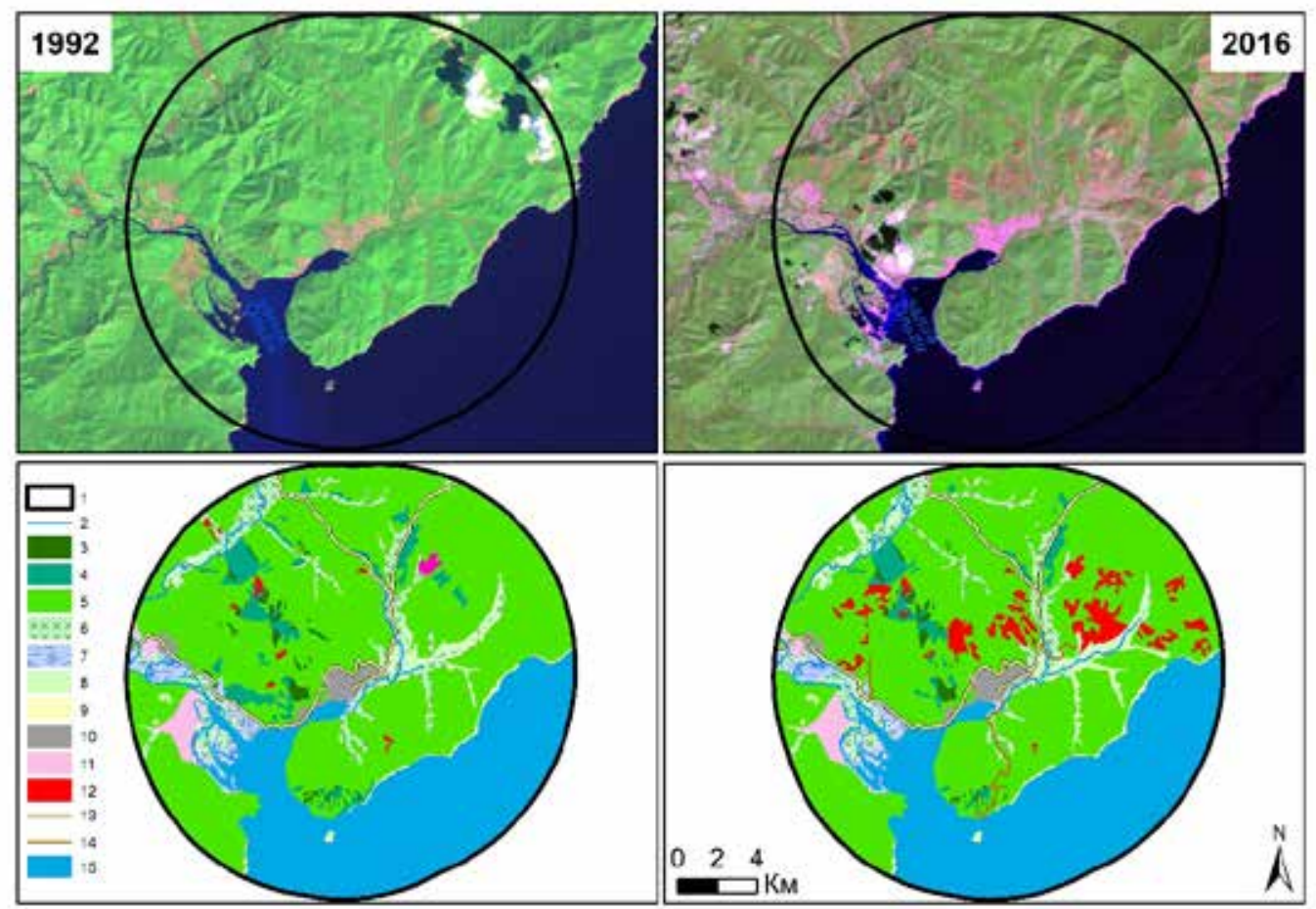

Рис. 2. Космические снимки и картографические результаты дешифрирования территории узлового приморского района развития «Ольга - залив Владимира», подрайон «Ольга». Верхний ряд: космические снимки; нижний ряд: карты ландшафтных комплексов для соответствующих временных срезов. Условные обозначения: 1 - буферная зона; 2 - реки; 3-6 - низкогорные лесные комплексы с преобладанием: 3 - хвойных (кедровых) лесов; 4 - хвойно (кедрово)-широколиственных лесов; 5 - широколиственных лесов; 6 - долинных (смешанных) лесов; 7-9 - низкогорные безлесные ландшафты с преобладанием: 7 - болот; 8 - лугов и кустарников; 9 - береговых обрывов и пляжей; 10-14 - антропогенные комплексы: 10 - селитебно-производственная инфраструктура; 11 - с/х земли; 12 - рубки; 13-14 - дороги: 13 - асфальтовые: 14 - грунтовые; 15 - водные поверхности

Fig. 2. The coastal areas of development "Olga-Vladimir Bay". Remote sensing images (top row) and landscape mapping result (bottom row). Legend: 1 - buffer zone; 2 - rivers; 3-6 - low-mountain forest complexes with a predominance: 3 - coniferous (cedar) forests; 4 -coniferous (cedar)-wide-leaf forests; 5 - wide-leaf forests; 6 - valley (mixed) forests; 7-9- low-mountain no forest complexes with a predominance: 7 - wetlands; 8 - meadows and shrubs; 9 - coastal cliffs and beaches; 10-14 - anthropogenic complexes; 10 - residential and production infrastructure; 11 - agricultural land; 12 - cutting; 13-14 - roads: 13 - asphalt; 14 - ground; 15 - water surface

Территория, непосредственно примыкающая к узловому району и находящаяся под его прямым воздействием, как в настоящее время, так и при потенциальном развитии, занимает площадь около 25 тыс. га. Около 80 \% площади занимают низкогорные ландшафты с широколиственными, преимущественно дубовыми, лесами. За последние 25 лет их площадь незначительно сократилась. В то же время существенные относительные изменения в сторону уменьшения отмечаются для ландшафтов с кедровыми (до $24 \%$ ) и кедрово-широколиственными лесами (до 33 \%). Однако, необходимо подчеркнуть, что в абсолютных значениях их распространение невелико и не превышает первых процентов. Более чем в 10 раз возросли площади рубок, что, однако, также не свидетельствует о резком возрастании антропогенных нагрузок на окружающую среду, так как на 2016 г. они составляют незначительную часть от лесного фонда рассматриваемой территории. Практически все рубки носят выборочный характер и сосредоточены в дубовых лесах. При этом фрагментации природных ландшафтов не наблюдается.

Доминирующее положение лесных и редколесных ландшафтов создаст эффект буфера при дальнейшем потенциальном развитии этих территорий как узловых приморских районов развития в прибрежных зонах и обеспечит устойчивость УПРР и прилегающих 
Экспликация изменения площадей ландшафтных комплексов узлового приморского района развития «Ольга - залив Владимира», подрайон Ольга за период 1992-2016 гг.

Table 2. Explication of the change of landscape complexes of the coastal area for development area «Olga-Vladimir Bay», subraion «Olga» for period 1992-2016 years.

\begin{tabular}{|l|r|r|r|}
\hline \multicolumn{1}{|l|}{ Природные и антропогенные комплексы } & \multicolumn{1}{|c|}{$\mathbf{1 9 9 2}$ г. } & \multicolumn{2}{|c|}{$\mathbf{2 0 1 6}$ г. } \\
\cline { 2 - 4 } Низкогорные лесные комплексы с преобладанием: & \multicolumn{1}{|c|}{ га } & \multicolumn{1}{|c|}{ га } & \multicolumn{1}{|c|}{ изменений } \\
хвойных (кедровых) лесов & 351,6 & 265,4 & $-24,5$ \\
хвойно (кедрово)-широколиственных лесов & 1427,5 & 952,4 & -33.3 \\
широколиственных (дубовых) лесов & 22079,1 & 21158,6 & $-4,2$ \\
долинных лесов & 2614,5 & 2563,6 & $-1,9$ \\
Низкогорные нелесные комплексы с преобладанием: & & & \\
болот & 797,2 & 797,3 & 0 \\
лугов & 579,5 & 853,2 & +4.7 \\
береговых осыпей и скал & 186,0 & 186,0 & 0 \\
Антропогенные комплексы: & & & \\
селитебно-производственная инфраструктура & 499,6 & 499,6 & 0 \\
рубки & 113,5 & 1464,0 & $+1185,0$ \\
с/х земли & 491,4 & 472,2 & $-3,9$ \\
\hline
\end{tabular}

территорий в отношении сохранения качества окружающей среды при возможном увеличении антропогенной нагрузки.

Для исследования структуры природных комплексов участка береговой зоны СихотэАлинского заповедника применялась аналогичная технология с теми же методическими этапами, что и для УПРР «Ольга-залив Владимира». Незначительные различия заключались лишь в этапе формирования классификации (легенды) и идентификации. Были классифицированы и картографированы следующие типы природных комплексов: а) равнин-

Таблица 3

Экспликация изменения площадей ландшафтных комплексов прибрежного участка СихотэАлинского заповедника за период 1992-2013 гг.

Table 3. Explication of the change of landscape complexes of the coastal area for coastal rayon of SikhoteAlin reserve for period 1992-2016 years

\begin{tabular}{|l|r|r|r|}
\hline \multicolumn{1}{|c|}{ Природные комплексы } & $\mathbf{1 9 9 2}$ г. & \multicolumn{2}{|c|}{$\mathbf{2 0 1 3}$ г. } \\
\cline { 2 - 4 } & \multicolumn{1}{|c|}{ га } & \multicolumn{1}{c|}{ га } & \% изменений \\
\hline Равнинные ландшафты с преобладанием: & & & \\
$\quad$ влажных лугов & 582,1 & 532,8 & $-8,5$ \\
сухих лугов и кустарников & 347,1 & 260,2 & $-25,0$ \\
$\quad$ песчаных пляжей & 46,7 & 50,1 & $+7,3$ \\
Низкогорные лесные ландшафты с преобладанием: & & & \\
$\quad$ дубовых лесов & 20764,8 & 18156,7 & $-12,5$ \\
кедровых лесов & 55,0 & 110,0 & $+100,0$ \\
$\quad$ лиственничных лесов & 270,7 & 529,6 & $+95,6$ \\
горно-долинных лесов (преимущественно & 1559,8 & 3910,2 & $+150,7$ \\
ольховников) & & & \\
Низкогорные нелесные ландшафты с преобладанием: & & & $-4,1$ \\
каменистых осыпей & 246,1 & 236,0 & $-11,3$ \\
береговых осыпей и скал & 403,7 & 358,2 & \\
\hline
\end{tabular}



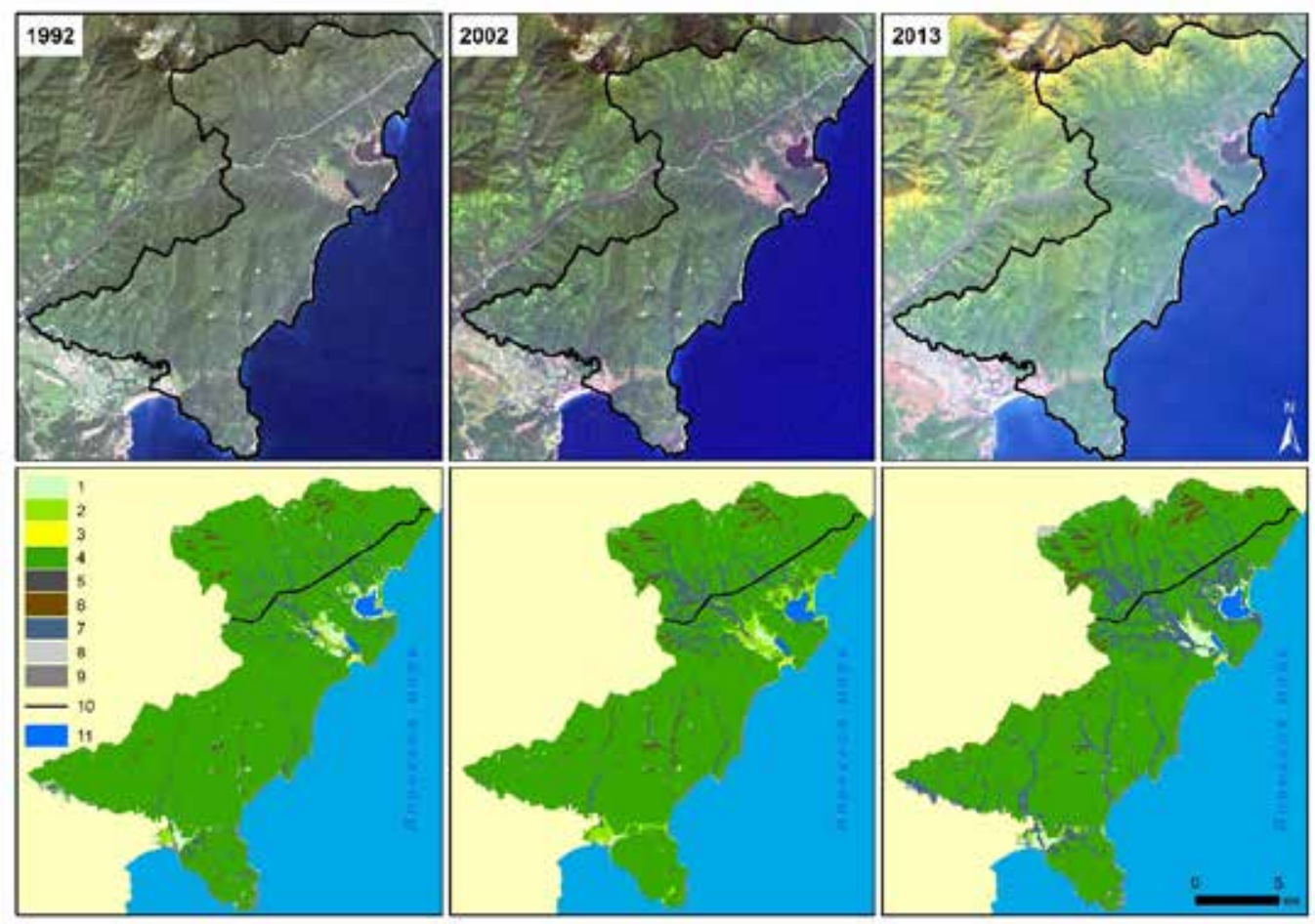

Рис. 3. Космические снимки и картографические результаты дешифрирования участка береговой зоны СихотэАлинского заповедника. Верхний ряд: космические снимки; нижний ряд: карты ландшафтных комплексов для соответствующих временных срезов. Условные обозначения: 1-3 - Равнинные ландшафты с преобладанием: 1 - влажных лугов; 2 - сухих лугов и кустарников; 3 - песчаных пляжей; 4-7 - Низкогорные лесные ландшафты с преобладанием: 4 - дубовых лесов; 5 - кедровых лесов; 6 - лиственничных лесов; 7 - горно-долинных лесов; 8-9 - Низкогорные безлесные ландшафты с преобладанием: 8 - каменистых осыпей; 9 - береговых скал и осыпей; 10 - дороги; 11 - водные поверхности

Fig. 3. The coastal rayon of Sikhote-Alin reserve. Remote sensing images (top row) and landscape mapping result (bottom row). Legend: 1-3 - Plain landscapes with predominance: 1 - wet meadows; 2 - dry meadows and shrubs; 3 sandy beaches; 4-7 - Low-mountain forest complexes with a predominance: 4 - oak forests; 5 - cedar forests; 6 - larch forests; 7 - mountain-valley forests; 8-9 - Low-mountain no forest complexes with a predominance: 8 - stony scree; 9 - coastal rocks and scree; 10 - roads; 11 - water surface

ные ландшафты с преобладанием: переувлажненных лугов; сухих лугов и кустарников; песчаных пляжей; б) низкогорные лесные ландшафты с преобладанием: дубовых лесов; кедровых лесов; лиственничных лесов; горно-долинных лесов; в) низкогорные нелесные ландшафты с преобладанием каменистых осыпей; прибрежных осыпей и скал (рис. 3). Незначительные различия в классификациях не являются препятствием для сравнительного анализа состояния ландшафтных комплексов и их изменений.

Изменения природных ландшафтов прибрежной зоны Сихотэ-Алинского заповедника происходят в естественном ключе без антропогенного вмешательства (рис. 3, табл. 3). Качественных изменений структуры ландшафтов не наблюдается. Из выявленных изменений за исследуемый период необходимо выделить значительное сокращение площадей низкогорных ландшафтов с преобладанием дубовых лесов (-12,5 \%), резкое увеличение площадей, занятых горно-долинными ландшафтами с преобладанием ольховников (+150\%), что может быть вызвано повышением увлажненности придолинных ландшафтов. Двукратное увеличение площадей кедровых и лиственничных лесов может быть обусловлено выходом указанных пород в верхний ярус, что привело к изменению спектрального образа пикселей. Соответственно уменьшение площадей равнинных ландшафтов с преобладанием сухих лугов и кустарников, вероятно, вызвано климатическими факторами. Расче- 
ты изменений значений вегетационного индекса за соответствующие периоды времени демонстрируют положительную динамику, что подтверждает увеличение фитомассы при естественных сукцессиях. Уменьшение значений за периоды 2002-2013 и 1992-2013 гг. вызвано более поздней датой снимка за 2013 г. - 29 сентября, ближе к окончанию вегетационного периода; снимки 1992 и 2002 гг. были получены 3 и 7 сентября соответственно.

Результаты дешифрирования ДДЗ, геоинформационное картографирование и проведенный анализ показывают, что критических и даже существенных изменений в ландшафтной структуре всех рассматриваемых ранее УПРР и территорий, находящихся в зоне их влияния, а также представленной в настоящей статье, не произошло. Естественные природные (местами - вторичные природные) ландшафты, преимущественно низкогорные и холмогорные лесные различного типа (в соответствии с широтной зональностью), а также редколесно-кустарниковые и луговые занимают более 50 \% площади во всех рассмотренных УПРР, достигая 85 \% («Ольга - залив Владимира»). Сравнительный анализ с изменениями, происшедшими в то же время в природных ландшафтах особо охраняемой территории, не выявил существенных различий в их развитии за последние 30-40 лет. Данный результат подтверждает высказанное ранее предположение о большой потенциальной емкости и устойчивости природно-территориальных комплексов при возможном достаточно интенсивном развитии узловых приморских районов Тихоокеанской России.

\section{Заключение и выводы}

Выполнено дешифрирование космических снимков и на основе анализа разновременных ДДЗ и геоинформационного картографирования проведена сравнительная оценка изменений природных и антропогенных комплексов территорий узлового района развития и участка Сихотэ-Алинского заповедника.

Установлено, что изменения природных ландшафтов прибрежной зоны Сихотэ-Алинского заповедника происходят в естественном ключе без антропогенного вмешательства, качественных изменений структуры ландшафтов не наблюдается. Двукратное увеличение площадей кедровых и лиственничных лесов может быть обусловлено выходом указанных пород в верхний ярус, что привело к изменению спектрального образа пикселей. Расчеты изменений значений вегетационного индекса за соответствующие периоды времени демонстрируют положительную динамику, что подтверждает увеличение фитомассы при естественных сукцессиях.

Показано, что критических и даже существенных изменений в ландшафтной структуре УПРР «Ольга - залив Владимира» и территорий, находящихся в зоне их влияния, не произошло. Естественные природные (местами - вторичные природные) ландшафты, преимущественно низкогорные и холмогорные лесные различного типа, а также редколесно-кустарниковые и луговые достигают 85 \% площади.

Сравнительный анализ подтверждает высказанное ранее предположение о большой потенциальной емкости и устойчивости природно-территориальных комплексов при возможном достаточно интенсивном развитии узловых приморских районов Тихоокеанской России и сохранении качества окружающей среды при возможном увеличении антропогенной нагрузки. Сравнительный анализ изменений природных и природно-антропогенных систем предоставляет новые возможности для понимания роли естественных и обусловленных хозяйственной деятельностью факторов динамики природно-территориальных комплексов береговой зоны Тихоокеанской России.

Исследование выполнено при частичной финансовой поддержке гранта РФФИ № 18-05-80006. 


\section{Литература}

1. Бакланов П.Я. Тихоокеанская Россия: географические и геополитические факторы развития // Известия РАН. Серия геогр. 2015. № 5. С. 8-19.

2. Бакланов П.Я., Ганзей К.С., Ермошин В.В. Береговые географические структуры в прибрежно-морском природопользовании // Докл. РАН. 2018. Т. 478, № 2. С. 229-231.

3. Бакланов П.Я., Ермошин В.В., Каракин В.П., Жариков В.В., Нгуен Ван Кы, Дин Чам Дао. Прибрежноморское природопользование в Тихоокеанской России и Северном Вьетнаме: понятия, структурные особенности и типы // География и природные ресурсы. 2017. № 4. С. 29-37.

4. Демографическая политика Российской Федерации на период до 2015 года [Электронный ресурс]. - http:// www.rosmintrud.ru/ministry/programs / (дата обращения: 13.11.2012).

5. Каракин В.П. Районирование береговой зоны Тихоокеанской России по природным условиям хозяйственного освоения // Сб. научных статей «Геосистемы в Северо-Восточной Азии. Типы, современное состояние и перспективы развития». Владивосток: Информационно-полиграфический центр ТИГ ДВО РАН, 2018. C. 601-608.

6. Базаров К.Ю., Ермошин В.В. Картографирование изменений природно-антропогенных комплексов узловых районов прибрежной зоны Тихоокеанской России на основе анализа временных рядов ДДЗ // Картография, геоинформатика и дистанционное зондирование: вызовы XXI века / ред. А.А.Медведев; Институт географии РАН. М.: Полиграфия СВС-Дизайн, 2019. С. 178-193.

7. Золотокрылин А.Н., Канцебовская И.В., Кренке А.Н. Районирование территории России по степени экстремальности природных условий жизни // Изв. АН. Серия геогр. 1992. № 6. С. 16-30.

8. Атлас природных и техногенных опасностей и рисков чрезвычайных ситуаций в Российской Федерации / под. ред. С.К. Шойгу. М.: ДИК, 2005. 270 с.

9. Назаревский О.Р. Карта оценки природных условий жизни населения СССР // Ресурсы, среда, расселение. М.: Наука, 1974. С. 189-199.

10. Демьяненко А.Н., Демьяненко Н.А. Опыт количественной оценки биоклиматических условий для целей регионального стратегирования (на примере Дальнего Востока) // Пространственная экономика. 2012. № 4. C. $138-154$.

11. Landsat8 [Электронный pecypc]. - https://landsat.usgs.gov/landsat-8 / (дата обращения: 10.05.2017).

12. Landsat5History [Электронный ресурс]. - https://landsat.usgs.gov/landsat-5-history / (дата обращения: 10.06.2017).

13. Sentinel2 [Электронный ресурс]. - https://sentinel.esa.int/web/sentinel/missions/sentinel-2 / (дата обращения: 15.05.2017).

14. Дубинин М.Ю. Corona - описание и получение данных [Электронный pecypc]. - http://gis-lab.info/qa/ corona.html / (дата обращения: 17.08.2016).

15. Xu Hanqiu Modification of normalized difference water index (NDWI) to enhance open water features in remotely sensed imagery // International J. of Remote Sensing. 2006. № 27. P. 3025-3033.

16. Базаров К.С. камеральное дешифрирование космогеоизображений трансграничных территорий на основе анализа спектральных яркостей // Геодезия и картография. 2012. № 11. С. 48-52.

17. Базаров К.С. Сравнительный анализ разновременных данных дистанционного зондирования территории государственного природного заповедника «Кедровая Падь» // Вестн. ДВО РАН. 2015. № 1 (179). С. $79-85$.

18. Венюков, М. И. Путешествия по окраинам русской Азии и записки о них / М. Венюкова, д.ч. Рус. геогр. о-ва. Санкт-Петербург: Тип. Имп. Акад. наук, 1868. II. 528 с.

\section{References}

1. Baklanov, P.Ya. Pacific Russia: geographical and geopolitical factors of development // Izvestiya RAS. Seriya Geograficheskaya. 2015, 5. 8-19. (In Russian)

2. Baklanov, P.Ya., Ganzey, K.S., Ermoshin, V.V. Coast geographical structure in coastal land use // Doklad RAS. 2018, Volume 478, 2, 229-231. (In Russian)

3. Baklanov, P.Ya., Ermoshin, V.V., Karakin, V.P., Zarikov, V.V., Nguen, Van Ki, Din, Cham Dao. Coastal land use in Pacific Russia and North Vietnam: terms, structure feature, and types // Geography and Nature Resources. 2017, 4, 29-37. (In Russian)

4. Demographic policy of Russian Federation for the period until 2015 year [E-Ressource]. - http://www. rosmintrud.ru/ministry/programs / (date of appeal 11.13.2012). (In Russian)

5. Karakin, V.P Districting of the Pacific Russia's coastal zone on natural conditions of economic development. A book of scientific articles "Geosystems in North-eastern Asia. Types, modern state and development prospects» Vladivostok: Information-poligrahhic Centre of PGI FEBRAS. 2018, 601-608. (In Russian)

6. Bazarov, K.Yu., Ermoshin, V.V. Mapping changes of natural-anthropogenic complexes of the development cores of the coastal zone of Pacific Russia based on analysis of remote sensing time series. Mapping, geoinformatics and 
remote sensing: challenges of the 21st century / Edited by A.A.Medvedev; Institute of Geography RAS. «Polygraphia SVS- Design»: Moskow, Russia. 2019, 178-193. (In Russian)

7. Zolotokrilin, A.N., Kantsebovskay, I,V., Krenke, A.N. Districting of the territory of Russia by the degree of extreme natural living conditions. Izvestiya RAS. Seriya Geograficheskaya. 1992, 6. 16-30. (In Russian)

8. Atlas of natural and technogenic dangers and risks of emergencies in the Russian Federation / Edited by S.K. Shoigu. DAM: Moskow, 2005; 270 p. (In Russian)

9. Nazarevskii O.R. Map of assessment of the natural living conditions of the population of the USSR. Resources, environmental, population. Nauka: Moskow, USSR. 1974, 189-199. (In Russian)

10. Demyanenko, A.N., Demyanenko, N.A. Experience of quantifying bioclimatic conditions for regional strategy (example of the Far East). Spatial economy. 2012, 4, 138-154. (In Russian)

11. Landsat8 [E-Ressource]. - https://landsat.usgs.gov/landsat-8 / (date of appeal 05.10. 2017).

12. Landsat5History [E-Ressource]. - https://landsat.usgs.gov/landsat-5-history / (date of appeal 06.10. 2017).

13. Sentinel2 [E-Ressource]. - https://sentinel.esa.int/web/sentinel/missions/sentinel-2/(date of appeal 05.15.2017).

14. Dubinin M.Yu. Corona - Description and data acquisition [E-Ressource]. - http://gis-lab.info/qa/corona.html / (date of appeal 08.17.2016). (In Russian)

15. Xu Hanqiu. Modification of normalized difference water index (NDWI) to enhance open water features in remotely sensed imagery. International Journal of Remote Sensing. 2006, 27, 3025-3033.

16. Bazarov K.Yu., Decryption of remote sensing data of cross-border territories based on spectral brightness analysis. Geodesy and cartography. 2012, 11, 48-52. (In Russian)

17. Bazarov K.Yu., Comparative analysis of different time remote sensing data for the territory of the "Cedar Pad" State Nature Reserve. Bulletin FEBRAS. 2015, 1 (179), 79-85. (In Russian)

18. Venyukov M.I. Travel to the outskirts of Russian Asia and note about them. RGS, Printing of Imperial Academy of Science: Sankt-Petersburg, Russia. 1868; II. 528 p. (In Russian) 